\title{
Kelayakan Investasi dengan Pendekatan Capital Asset Pricing Model Untuk Saham Kapitalisasi Terbesar di Bursa Efek Indonesia
}

\author{
Irma Setyawati ${ }^{1, *}$, Molina ${ }^{1}$, Muhani ${ }^{1}$, Irennizha Eka Widya Nurul Huda ${ }^{1}$ \\ ${ }^{1}$ Fakultas Ekonomi dan Bisnis; Universitas Nasional; Jl. Sawo Manila Pasar Minggu Jakarta; \\ Telp 021 - 7806700; e-mail: irmasetyawati@civitas.unas.ac.id, molina@civitas.unas.ac.id, \\ muhani@civitas.unas.ac.id, irennizha.eka@gmail.com \\ * Korespondensi: e-mail: irmasetyawati@civitas.unas.ac.id
}

Submitted: 31/08/2021; Revised: 03/09/2021; Accepted: 10/09/2021; Published: 30/09/2021

\begin{abstract}
The purpose of this study is to determine the feasibility of investing in stocks with the largest capitalization on the Indonesia Stock Exchange. This study was analyzed using the Capital Asset Pricing Model approach. The data used is secondary data, namely the stock price and trading volume of companies indexed LQ45 for the period August 2019 - July 2021, the Composite Stock Price Index, and the Bank Indonesia 7 Days Repo Rate. The analyzed companies are 5 (five) companies that have the largest trading volume during the study period. The results of the study that PT. Aneka Tambang (Persero), Tbk has the highest rate of return. While the other two companies have negative returns, namely Perusahaan Gas Negara, Tbk and Telkom Indonesia (Persero) Tbk. Stocks of PT. Aneka Tambang (Persero), Tbk has the largest level of risk, while the company whose stocks have the smallest level of risk is Telkom Indonesia (Persero) Tbk. The excess returns of almost all stocks are positive, meaning that they are worth investing in, namely the stocks of PT. Aneka Tambang (Persero), Tbk, Perusahaan Gas Negara, Tbk, Tower Bersama Infrastructure Tbk. and stocks of Bank Rakyat Indonesia (Persero), Tbk. Inappropriate investment in stocks of Telkom Indonesia (Persero) Tbk. Stocks that are eligible to be purchased by investors are stocks that have a positive excess return.
\end{abstract}

Keywords: Capital Asset Pricing Model, Investment, LQ45, Stocks.

\begin{abstract}
Abstrak
Tujuan penelitian ini untuk mengetahui kelayakan investasi pada saham kapitalisasi terbesar di Bursa Efek Indonesia. Penelitian ini dianalisis dengan pendekatan Capital Asset Pricing Model. Data yang digunakan adalah data sekunder, yaitu harga saham dan volume perdagangan perusahaan terindeks LQ45 periode Agustus 2019 - Juli 2021, Indeks Harga Saham Gabungan, dan Bank Indonesia 7Days Repo Rate. Perusahaan yang dianalisis adalah 5 (lima) perusahaan yang memiliki volume perdagangan tersebesar selama periode penelitian. Hasil penelitian bahwa PT. Aneka Tambang (Persero), Tbk mempunyai tingkat pengembalian paling tinggi. Sedangkan dua perusahaan lainnya mempunyai tingkat pengembalian negatif, yaitu Perusahaan Gas Negara, Tbk dan Telkom Indonesia (Persero) Tbk. Saham PT. Aneka Tambang (Persero), Tbk mempunyai tingkat risiko terbesar, sedang perusahaan yang sahamnya mempunyai tingkat risiko terkecil adalah Telkom Indonesia (Persero) Tbk. Excess return hampir semua saham bernilai positif, artinya layak untuk diinvestasikan, yaitu saham PT. Aneka Tambang (Persero), Tbk, Perusahaan Gas Negara, Tbk, Tower Bersama Infrastructure Tbk. dan saham perusahaan Bank Rakyat Indonesia (Persero), Tbk. Investasi yang tidak layak ditanamkan pada saham Telkom Indonesia (Persero) Tbk. Saham yang layak untuk dibeli oleh investor adalah saham karena memiliki excess return positif.
\end{abstract}

Kata kunci: Capital Asset Pricing Model, Investasi, LQ45, Saham 


\section{Pendahuluan}

Sejalan dengan semakin terbukanya perekonomian Indonesia terhadap perekonomian dunia, perkembangan dunia usaha di tanah air banyak mengalami kemajuan, ini dapat dilihat dari banyaknya perusahaan, baik lembaga keuangan dan non-lembaga keuangan yang berdiri dalam rangka meningkatkan dan menunjang kegiatan perekonomian di Indonesia. Untuk itu, suatu perusahaan harus selalu memperbaiki dan mengembangkan kinerja perusahaan agar dapat bersaing dengan perusahaan lain, sehingga dibutuhkan tambahan modal yang cukup banyak (Setyawati, 2018). Salah satu cara untuk mendapatkan dana dengan memobilisasi dana masyarakat lewat penerbitan saham. Dana yang dikumpulkan lewat Initial Public Offering (IPO), digunakan oleh perusahaan untuk memperbaiki dan mengembangkan kinerja perusahaan tersebut. Saham biasa yang diperjual-belikan merupakan salah satu dari surat berharga yang menunjukkan kepemilikan dari suatu perusahaan, yang di dalamnya terdapat hak untuk memperoleh bagian dari proses kekayaan perusahaan yang menerbitkan saham tersebut, sedangkan pasar modal merupakan tempat bertemunya permintaan dan penawaran atas surat-surat berharga termasuk di dalamnya saham suatu perusahaan (Ogiugo et al., 2020).

Investor dapat menginvestasikan dananya dengan melakukan jual beli saham melalui pasar modal, dengan mengharapkan adanya suatu tingkat pengembalian yang akan diperoleh dari pembagian deviden dan capital gain, sehingga penting bagi para investor untuk mempertimbangkan alternatif investasi tersebut dengan melakukan pengelolaan secara hatihati dengan mempertimbangkan tingkat pengembalian dan risiko yang ditimbulkan akibat memilih salah satu dari alternatif investasi (Harshita et al., 2015). Pada prinsipnya investor yang rasional akan selalu memilih investasi yang akan memberikan tingkat pengembalian yang maksimal dengan risiko tertentu atau memilih investasi yang memberikan tingkat pengembalian tertentu dengan risiko yang minimal (Setyawati, 2014). Don't put all your eggs into one basket merupakan kaidah investasi yang diberikankan kepada semua investor. Intinya adalah semua jenis investasi pasti ada risikonya, maka sebaiknya jangan menginvestasikan seluruh dana dalam satu aset, karena jika terjadi sesuatu atas aset tersebut, maka semua dana investasi yang dimiliki akan habis. Slogan di atas merupakan implementasi prinsip diversifikasi (penyebaran) investasi untuk mengurangi risiko (Oldfield \& Santomero, 2014).

Salah satu cara yang dapat dilakukan oleh investor untuk memunimumkan risiko adalah dengan menganalisis kelayakan investasi suatu saham. Investor dapat menggunakan Capital Assets Pricing Model (CAPM) yang merupakan bentuk pengembangan teori portofolio dari Markowitz. Teori portofolio Markowitz (1952 - 1959) menyatakan bahwa diversifikasi dalam penyusunan portofolio bermanfaat menurunkan risiko investasi (Marling and \& Emanuelsson, 2012). Pernyataan tersebut berdasarkan pada pengamatan bahwa para investor di bursa yang melakukan diversifikasi dalam melakukan investasi pada sekumpulan saham sebagai upaya mengurangi risiko dari sejumlah saham yang dibeli. CAPM menyatakan ada hubungan positif antara tingkat pengembalian yang layak dengan risiko. Ini menunjukkan semakin besar risiko melekat pada sejumlah saham akibat fluktuasi harga saham, semakin besar tingkat 
pengembalian yang diharapkan pada saham tersebut. Selain itu, CAPM memasukkan tingkat suku bunga aset bebas risiko (Rf) dan tingkat pengembalian portofolio pasar $(\mathrm{Rm})$ dalam menetukan tingkat pengembalian yang layak atas suatu saham (Širůček \& Křen, 2015; Matsuk, Shyiko, Danyliuk-Chernykh, \& Tryshak, 2019).

Instrumen BI 7-Day Repo Rate digunakan sebagai tingkat suku bunga yang dikeluarkan oleh otoritas moneter menggantikan Bank Indonesia Rate (BI Rate) dengan tujuan untuk memengaruhi pasar uang, perbankan dan sektor riil secara cepat. BI-7 Day Repo Rate (BI7DRR) berlaku efektif sejak 19 Agustus 2016. Perubahan aturan kebijakan ini merupakan best practice internasional dalam rangka menjalankan tugas Bank Indonesia sebagai otoritas moneter dalam menjalankan kebijakan moneter. Framework operasi moneter selalu diperbaiki dalam rangka tercapainya tujuan utama, yaitu besaran inflasi yang ditetapkan. BI 7-Day Repo Rate dijadikan sebagai acuan dalam menentukan suku bunga pasar uang, bagi instrumen pasar uang yang mempunyai sifat transaksional, dan mendorong pendalaman pasar keuangan, khususnya penggunaan instrumen repo. Keuntungan sebesar tingkat suku bunga bebas risiko ini merupakan tingkat pengembalian yang akan diterima investor terlepas dari besar kecilnya risiko yang terkandung dalam sejumlah saham (pada beta sama dengan nol), sedangkan tingkat pengembalian merupakan tingkat pengembalian rata-rata dari seluruh kesempatan investasi (indeks pasar) (Setyawati, 2014).

Di Indonesia indeks pasar yang digunakan adalah indeks harga saham gabungan (IHSG), yang telah diperkenalkan sejak tanggal 1 April 1983 untuk pertama kalinya sebagai indikator untuk memantau pergerakan saham. Kemudian pada tanggal 24 Februari 1997 Bursa Efek Indonesia memperkenalkan indeks baru kepada para pelaku dan investor di pasar modal yaitu LQ45, yang hanya terdiri dari 45 saham dari perusahaan-perusahaan yang telah diplih setelah melalui beberapa kriteria pemilihan yang ketat, sehingga akan menjadi saham-saham dengan likuiditas tinggi dan juga mempertimbangkan kapitalisasi pasar saham tersebut. Namun, indeks LQ45 tidak dimaksudkan untuk mengganti IHSG maupun indeks sektoral yang digunakan saat ini (Jayana \& Gayatri, 2018). Indeks Harga Saham Gabungan dapat membantu bagi para manajer investasi maupun para pelaku dan investor dipasar modal menjadi lebih tajam dan objektif, terutama ketika menilai pergerakan saham-saham yang ditransaksikan di Bursa Efek Indonesia (BEI). Kebutuhan investor akan perkiraan tingkat pengembalian dari dana yang akan diinvestasikan pada sejumlah saham menjadikan CAPM penting artinya sebagai model penelitian atas sejumlah saham, di mana hasil yang akan di dapat dari proses perhitungan dengan menggunakan CAPM tersebut dapat memberikan masukan bagi investor untuk dapat menentukan pilihan atas jenis saham yang yang layak diinvestasikan di BEI.

Tujuan dari penelitian ini adalah untuk mengetahui kelayakan investasi pada sahamsaham kapitalisasi terbesar di BEl. Dengan dilaksanakannya penelitian ini diharapkan dapat menjadi masukan bagi para pembaca dalam menghitung kelayakan investasi pada sahamsaham kapitalisasi terbesar di BEI. 


\section{Metode Penelitian}

Penelitian dilaksanakan dengan mengakses data IHSG, harga saham, volume perdagangan saham listing di Bursa Efek Indonesia di idx.go.id. dan BI 7Days Repo Rate diakses dari Bank Indonesia di bi.go.id. Jenis data yang digunakan adalah data sekunder, yaitu data berupa harga saham dan volume perdagangan perusahaan yang terindeks LQ45 periode Agustus 2019 - Juli 2021, IHSG, dan BI 7Days Repo Rate. Perusahaan yang akan dianalisis adalah 5 (lima) perusahaan yang memiliki volume perdagangan tersebesar selama periode penelitian. Tabel 1 menunjukkan variabel yang digunakan dalam menganalisis kelayakan investasi dengan pendekatan CAPM untuk saham-saham kapitalisasi terbesar.

Tabel 1. Variabel yang Digunakan dalam Analisis Kelayakan Saham

\begin{tabular}{clll}
\hline \multicolumn{1}{c}{ Variabel } & \multicolumn{1}{c}{ Indikator } & \multicolumn{1}{c}{ Ukuran } & Skala \\
\hline & Harga Saham & Closed Price & Rasio \\
& Tingkat Risiko & Standar Deviasi & Rasio \\
& Tingkat Pengembalian Saham & Return realisasi & Rasio \\
CAPM & Tingkat Aset Bebas Risiko & BI 7Days Repo Rate & Rasio \\
& Expected Return & Return realisasi per periode & Rasio \\
& Required Return & Aset bebas risiko, beta saham dan & Rasio \\
& Excess Return & risiko pasar & Rasio \\
\hline
\end{tabular}

Sumber: Hasil Penelitian (2021)

Analisis data yang dilakukan dengan pendekatan CAPM, sehingga dapat diketahui kelayakan saham yang diinvestasikan. Langkah-langkah yang digunakan dalam analisis CAPM adalah sebagai berikut:

a. Mencari return realisasi.

$$
\begin{gathered}
R_{i}=\frac{I H S G_{t}-I H S G_{t-1}}{I H S G_{t-1}} \\
\text { Di mana }: \text { IHSGt }=\quad \text { IHSG pada bulan tertentu } \\
\text { IHSG } \quad=\quad \text { IHSG pada bulan sebelumnya } \\
\text { Ri } \quad=\quad \text { Tingkat pengembalian saham individu }
\end{gathered}
$$

b. Mencari tingkat pengembalian saham, variance dan risiko

$$
\begin{array}{lll}
E(R)_{i \bar{i}}=\frac{\sum_{i=1}^{n} R_{i \bar{i}}}{n} & \\
\text { Di mana: } & \mathrm{E}(\mathrm{Ri})= & \text { Tingkat pengembalian saham yang diharapkan } \\
\mathrm{Ri} & = & \text { Tingkat pengembalian saham } \\
\mathrm{n} & =\quad \text { Banyaknya jumlah bulan } \\
\sigma^{2}=\left[R_{i}-E\left(R_{i}\right)\right]^{2} & \\
\text { Di mana: } & \sigma^{2}= & \text { Variance Return } \\
(\mathrm{Ri}) & = & \text { Return ke I yang mungkin akan terjadi } \\
\mathrm{E}(\mathrm{Ri}) & = & \text { Return yang diharapkan dari sekuritas } \mathrm{i}
\end{array}
$$




$$
\sigma=\sqrt{\sigma^{2}}
$$
Di mana:
$\sigma \quad=$
Standar deviasi

c. Menentukan besarnya Systematic Risk $(\beta)$ dari saham yang akan dianalisis

$$
\begin{array}{llll}
\beta=\frac{\sigma_{\text {im }}}{\sigma_{m}^{2}} & & \\
\text { Di mana: } & \sigma^{2} m= & \text { Variance pasar } \\
& \sum \mathrm{im}= & \text { Variance sekuritas }
\end{array}
$$

d. $\quad$ Mencari required return

$$
R R=R_{f}+\left[E\left(R_{m}\right)-R_{f}\right] \beta_{i}
$$

$\begin{array}{llll}\text { Di mana: } & \mathrm{Rf} & = & \text { Aset bebas risiko } \\ \mathrm{E}(\mathrm{Rm}) & = & \text { Tingkat pengembalian pasar } \\ \mathrm{\beta i} & = & \text { Beta }\end{array}$

e. Mencari besarnya selisih excess return untuk menetukan pengembalian keputusan pembelian saham

$$
\begin{array}{lll}
E(R)=E\left(R_{i}\right)-R R & \\
\text { Di mana: } & \mathrm{RR}= & \text { Tingkat pengembalian portofolio } \\
& \mathrm{E}(\mathrm{Ri})= & \text { Tingkat pengembalian yang diharapkan dari saham. }
\end{array}
$$

f. Mengambil keputusan pembelian saham

Jika $E(R i)>R R$, maka saham tersebut layak untuk dibeli

Jika $E(R i)<R R$, maka saham tersebut tidak layak untuk dibeli.

Hipotesis dari penelitian ini sebagai berikut:

H1 : $\quad$ Saham-saham kapitalisasi terbesar di BEl layak untuk investasi.

H2 : Saham-saham kapitalisasi terbesar di BEl tidak layak untuk investasi.

\section{Hasil dan Pembahasan}

\subsection{Data Hasil Penelitian}

Untuk melakukan analisis kelayakan investasi dengan pendekatan CAPM, digunakan data berupa harga saham 5 (lima) perusahaan yang memiliki volume perdagangan terbesar selama periode penelitian. Adapun perusahaan dimaksud disajikan pada tabel 2.

Tabel 2. Nama Perusahaan dan Volume Perdagangan

\begin{tabular}{clc}
\hline No. & \multicolumn{1}{c}{ Nama Perusahaan } & Volume Perdagangan \\
\hline 1. & PT Aneka Tambang (Persero), Tbk (ANTM) & 21.184 .332 .900 \\
2. & Perusahaan Gas Negara, Tbk (PGAS) & 7.940 .322 .900 \\
3. & Tower Bersama Infrastructure Tbk. (TOWR) & 7.124 .803 .300 \\
4. & Bank Rakyat Indonesia (Persero) Tbk. (BBRI) & 6.235 .053 .200 \\
5. & Telkom Indonesia (Persero) Tbk. (TLKM) & 5.838 .181 .000 \\
\hline
\end{tabular}

Sumber: Hasil Pengolahan Data (2021) 
Selanjutnya digunakan data berupa harga saham kesepuluh perusahaan, indeks harga saham gabungan (IHSG), dan BI 7Days Repo Rate periode Agustus 2019 - Juli 2021 yang tersaji pada tabel 3 .

Tabel 3. Harga Saham Perusahaan, IHSG, BI 7Days Repo Rate

\begin{tabular}{|c|c|c|c|c|c|c|c|c|}
\hline Tahun & Bulan & ANTM & PGAS & TOWR & BBRI & TLKM & BI7DRR & IHSG \\
\hline \multirow{3}{*}{2019} & September & 975 & 2.100 & 655 & 4.120 & 10.550 & $5,25 \%$ & 968,15 \\
\hline & November & 750 & 1.920 & 730 & 4.090 & 9.200 & $5,00 \%$ & 956,82 \\
\hline & Desember & 840 & 2.170 & 805 & 4.400 & 10.275 & $5,00 \%$ & $1.014,47$ \\
\hline \multirow[t]{7}{*}{2020} & Januari & 720 & 1.705 & 845 & 4.460 & 9.100 & $5,00 \%$ & 961,98 \\
\hline & April & 510 & 855 & 900 & 2.730 & 5.000 & $4,50 \%$ & 713,64 \\
\hline & Mei & 535 & 860 & 955 & 2.950 & 3.970 & $4,50 \%$ & 725,83 \\
\hline & Juni & 605 & 1.135 & 1.020 & 3.030 & 5.150 & $4,25 \%$ & 756,20 \\
\hline & Juli & 730 & 1.265 & 1.135 & 3.160 & 6.750 & $4,00 \%$ & 803,01 \\
\hline & Agustus & 820 & 1.255 & 1.035 & 3.510 & 6.825 & $4,00 \%$ & 824,19 \\
\hline & September & 705 & 925 & 1.035 & 3.040 & 6.050 & $4,00 \%$ & 737,15 \\
\hline \multirow[t]{7}{*}{2021} & Januari & 2.220 & 1.345 & 960 & 4.180 & 13.200 & $3,75 \%$ & 911,98 \\
\hline & Februari & 2.840 & 1.440 & 1.265 & 4.710 & 14.775 & $3,50 \%$ & 944,75 \\
\hline & Maret & 2.250 & 1.315 & 1.100 & 4.400 & 10.425 & $3,50 \%$ & 902,79 \\
\hline & April & 2.490 & 1.225 & 1.140 & 4.050 & 9.975 & $3,50 \%$ & 893,73 \\
\hline & Mei & 2.450 & 1.115 & 1.175 & 4.260 & 9.225 & $3,50 \%$ & 888,65 \\
\hline & Juni & 2.300 & 1.005 & 1.240 & 3.940 & 7.800 & $3,50 \%$ & 844,85 \\
\hline & Juli & 2.540 & 995 & 1.315 & 3.780 & 7.525 & $3,50 \%$ & 835,73 \\
\hline
\end{tabular}

\subsection{Analisis Data}

Menentukan tingkat kelayakan investasi saham, yaitu dengan membandingkan excess return antara tingkat pengembalian yang diharapkan dari saham individu $E(R i)$ dengan tingkat pengembalian yang diminta oleh investor (required return).

Pengambilan keputusan dari penanaman dana investor pada saham setelah mengetahui besarnya kelebihan hasil pengembalian saham. Keputusan tersebut menggunakan kriteria jika excess return lebih besar dari nol, maka saham tersebut layak untuk diinvestasikan. Sebaliknya jika excess return lebih kecil dari nol, maka saham tersebut tidak layak untuk diinvestasikan. Adapun analisis kelayakan investasi dengan pendekatan CAPM melalui beberapa tahapan, diantaranya a) Menghitung return realisasi; b) Menghitung tingkat pengembalian yang diharapkan dan risiko dari tiap saham; c) mencari beta; d) Menghitung required return (tingkat pengembalian yang diharapkan oleh investor untuk sekuritas); e) excess return. Menghitung return realisasi, Tabel 4 adalah return realisasi dari masing-masing saham yang diperoleh dengan cara mengurangkan harga saham individu pada bulan tertentu dengan harga saham pada bulan sebelumnya dibagi dengan harga saham individu pada bulan sebelumnya. 
Tabel 4. Return Realisasi

\begin{tabular}{|c|c|c|c|c|c|c|}
\hline Tahun & $\begin{array}{r}\text { Perusahaan } \\
\text { Bulan }\end{array}$ & ANTM & PGAS & TOWR & BBRI & TLKM \\
\hline \multirow[t]{5}{*}{2019} & Agustus & & & & & \\
\hline & September & $-0,089$ & 0,094 & $-0,071$ & $-0,035$ & $-0,031$ \\
\hline & Oktober & $-0,087$ & 0,005 & 0,008 & 0,022 & $-0,046$ \\
\hline & November & $-0,157$ & $-0,090$ & 0,106 & $-0,029$ & $-0,044$ \\
\hline & Desember & 0,120 & 0,130 & 0,103 & 0,076 & 0,010 \\
\hline \multirow[t]{12}{*}{2020} & Januari & $-0,143$ & $-0,214$ & 0,050 & 0,014 & $-0,043$ \\
\hline & Februari & $-0,201$ & $-0,249$ & $-0,047$ & $-0,061$ & $-0,082$ \\
\hline & Maret & $-0,217$ & $-0,395$ & $-0,161$ & $-0,279$ & $-0,095$ \\
\hline & April & 0,133 & 0,103 & 0,333 & $-0,096$ & 0,108 \\
\hline & Mei & 0,049 & 0,006 & 0,061 & 0,081 & $-0,100$ \\
\hline & Juni & 0,131 & 0,320 & 0,068 & 0,027 & $-0,032$ \\
\hline & Juli & 0,207 & 0,115 & 0,113 & 0,043 & 0,000 \\
\hline & Agustus & 0,123 & $-0,008$ & $-0,088$ & 0,111 & $-0,062$ \\
\hline & September & $-0,140$ & $-0,263$ & 0,000 & $-0,134$ & $-0,105$ \\
\hline & Oktober & 0,496 & 0,162 & $-0,043$ & 0,105 & 0,023 \\
\hline & November & 0,085 & 0,293 & 0,106 & 0,217 & 0,233 \\
\hline & Desember & 0,690 & 0,191 & $-0,123$ & 0,020 & 0,025 \\
\hline \multirow[t]{7}{*}{2021} & Januari & 0,147 & $-0,187$ & 0,000 & 0,002 & $-0,060$ \\
\hline & Februari & 0,279 & 0,071 & 0,318 & 0,127 & 0,122 \\
\hline & Maret & $-0,208$ & $-0,087$ & $-0,130$ & $-0,066$ & $-0,020$ \\
\hline & April & 0,107 & $-0,068$ & 0,036 & $-0,080$ & $-0,064$ \\
\hline & Mei & $-0,016$ & $-0,090$ & 0,031 & 0,052 & 0,075 \\
\hline & Juni & $-0,061$ & $-0,099$ & 0,055 & $-0,075$ & $-0,084$ \\
\hline & Juli & 0,104 & $-0,010$ & 0,060 & $-0,041$ & $-0,025$ \\
\hline
\end{tabular}

Sumber: Hasil Pengolahan Data (2021)

Menghitung tingkat pengembalian yang diharapkan dan risiko dari tiap saham. Tabel 5 menunjukkan tingkat pengembalian yang diharapkan dari tiap saham $E(R i)$ dan risiko dari tiap saham yang dinyatakan dalam bentuk standar deviasi.

Tabel 5. Tingkat Pengembalian dan Risiko Tiap Saham

\begin{tabular}{cccccc}
\hline & ANTM & PGAS & TOWR & BBRI & TLKM \\
\hline E $($ Ri) & 0,059 & $(0,012)$ & 0,034 & 0,00006 & $(0,013)$ \\
Variance & 0,050 & 0,032 & 0,015 & 0,011 & 0,007 \\
STDEV & 0,223 & 0,179 & 0,122 & 0,103 & 0,082 \\
\hline Sumber: Hasil Pengolahan Data (2021) & & &
\end{tabular}

Berdasarkan tabel 5, PT. Aneka Tambang (Persero), Tbk mempunyai tingkat pengembalian saham paling tinggi sebesar 5,9\%, kemudian, Tower Bersama Infrastruktur Tbk mempunyai tingkat pengembalian sebesar 3,4\% dan Bank Rakyat Indonesia (Persero), Tbk mempunyai tingkat pengembalian sebesar $0,006 \%$. Sedangkan dua perusahaan lainnya mempunyai tingkat pengembalian yang negatif, yaitu saham Perusahaan Gas Negara, Tbk sebesar $-1,2 \%$ dan Telkom Indonesia (Persero) Tbk dengan tingkat pengembalian paling rendah sebesar $-1,3 \%$. Standar deviasi menunjukan tingkat risiko masing-masing saham. Perusahaan yang mempunyai tingkat risiko paling rendah adalah saham Telkom Indonesia (Persero) Tbk mempunyai tingkat risiko sebesar 8,2\%, kemudian saham Bank Rakyat Indonesia (Persero), Tbk dengan tingkat risiko sebesar 10,3\%. Perusahaan Gas Negara, Tbk dengan tingkat risiko terkecil sebesar $-1,8 \%$, kemudian. Saham perusahaan Tower Bersama Infrastruktur Tbk tingkat risiko sebesar $12,2 \%$. Saham yang memiliki tingkat risiko tertinggi adalah PT. Aneka Tambang (Persero), Tbk sebesar 22,3\%.

Berdasarkan hasil perhitungan tingkat pengembalian saham dan tingkat risiko, maka PT. Aneka Tambang (Persero), Tbk memiliki tingkat pengembalian saham tertinggi tetapi tingkat risikonya juga paling tinggi. Sedangkan saham Telkom Indonesia (Persero) Tbk memiliki 
tingkat pengembalian saham terendah dan tingkat risikonya juga rendah. Hal ini berarti tingkat pengembalan saham berbanding lurus dengan tingkat risiko. Semakin tinggi tingkat pengembalian saham maka semakin tinggi risikonya. Tahap mencari beta, untuk mencari beta digunakan single indeks model, dimana beta menunjukan sensitivitas return saham terhadap perubahan pasar yang ditunjukkan IHSG.

Tabel 6. Beta dalam Single Indeks Model

\begin{tabular}{cccccc} 
& ANTM & PGAS & TOWR & BBRI & TLKM \\
\hline Alpha & 0,070 & $(0,0001)$ & 0,038 & 0,006 & $(0,009)$ \\
Beta & 2,167 & 2,297 & 0,738 & 1,257 & 0,752 \\
Variance ei & 0,211 & 0,144 & 0,005 & 0,009 & 0,001 \\
\hline Sumber: & & &
\end{tabular}

Sumber: Hasil Pengolahan Data (2021)

Dari tabel 6 terlihat bahwa dari kelima perusahaan, terdapat 3 (tiga) perusahaan yang memiliki $\beta>1$, yaitu saham Perusahaan Gas Negara, Tbk, PT. Aneka Tambang (Persero), Tbk, dan Bank Rakyat Indonesia (Persero), Tbk. Saham dengan beta lebih besar dari satu disebut saham agresif, artinya kalau terjadi perubahan tingkat pengembalian portofolio pasar sebesar $1 \%$, maka tingkat pengembalian saham tersebut berubah dengan arah yang sama dan lebih besar lebih dari 1\% (Wu et al., 2017). Sedangkan Tower Bersama Infrastruktur Tbk dan Telkom Indonesua (Persero) Tbk mempunyai memiliki $\beta<1$, sehingga disebut saham defensif. Berdasarkan tabel 6 , dapat dibuat persamaan regresi bagi tiap-tiap saham sebagai berikut: a) Regresi saham PT. Aneka Tambang (Persero), Tbk. b) Regresi saham Perusahaan Gas Negara, Tbk. c) Regresi saham Tower Bersama Infrastruktur Tbk. d) Regresi saham Bank Rakyat Indonesia (Persero) Tbk. e) Regresi saham Telkom Indonesia (Persero) Tbk.

Regresi saham PT. Aneka Tambang (Persero), Tbk. diperoleh $\mathbf{E}\left(\mathbf{R}_{\text {ANTM }}\right)=\mathbf{0 , 0 7}+\mathbf{2 , 1 6 7}$ $\mathbf{E}\left(\mathbf{R}_{\mathbf{M}}\right)$. Di mana: Alfa $=0,07$; artinya apabila tingkat pengembalian pasar adalah 0 (ditunjukkan dengan IHSG), maka tingkat pengembalian saham $E\left(R_{\text {ANTM }}\right)$ sebesar 2,167 (positif). Beta = 2,167; artinya setiap ada kenaikan return pasar sebesar $1 \%$, maka return saham PT. Aneka Tambang (Persero), Tbk akan mengalami kenaikan sebesar 2,167\%, dan sebaliknya.

Regresi saham Perusahaan Gas Negara, Tbk. diperoleh $E\left(R_{\text {PGAS }}\right)=\mathbf{- 0 , 0 0 0 1 + 2 , 2 9 7}$ $\mathbf{E}\left(\mathbf{R}_{\mathbf{M}}\right)$. Di mana: Alfa $=-0,00001$; artinya apabila tingkat pengembalian pasar adalah 0 (ditunjukkan dengan IHSG), maka tingkat pengembalian saham $E$ (RPGAS) sebesar 0,0001 (negatif). Beta $=2,297$; artinya setiap ada kenaikan return pasar sebesar $1 \%$, maka return saham Perusahaan Gas Negara, Tbk akan mengalami kenaikan sebesar 2,297\%, dan sebaliknya.

Regresi saham Tower Bersama Infrastruktur Tbk. diperoleh $\mathbf{E}\left(\mathbf{R}_{\mathrm{TWR}}\right)=\mathbf{0 , 0 3 8}+\mathbf{0 , 7 3 8}$ $\mathbf{E}\left(\mathbf{R}_{\mathbf{M}}\right)$. Di mana: Alfa $=0,038$; artinya apabila tingkat pengembalian pasar adalah 0 (ditunjukkan dengan IHSG), maka tingkat pengembalian saham $E\left(R_{T W R}\right)$ sebesar 0,038 (positif). Beta = 0,738; artinya setiap ada kenaikan return pasar sebesar $1 \%$, maka return saham Tower Bersama Infrastruktur Tbk.akan mengalami kenaikan sebesar 0,738\%, dan sebaliknya.

Regresi saham Bank Rakyat Indonesia (Persero) Tbk. diperoleh $\mathbf{E}\left(\mathbf{R}_{\mathrm{BBRI}}\right) \mathbf{= 0 , 0 0 6 +}$ 1,257 $\mathbf{E}\left(\mathbf{R}_{\mathbf{M}}\right)$. Di mana: Alfa $=0,006$; artinya apabila tingkat pengembalian pasar adalah 0 (ditunjukkan dengan IHSG), maka tingkat pengembalian saham $E\left(R_{B B R I}\right)$ sebesar 0,006 (positif). 
Beta $=1,257$; artinya setiap ada kenaikan return pasar sebesar $1 \%$, maka return saham Bank Rakyat Indonesia (Persero) Tbk akan mengalami kenaikan sebesar 1,257\%, dan sebaliknya.

Regresi saham Telkom Indonesia (Persero) Tbk. diperoleh $\mathbf{E}\left(\mathbf{R}_{\mathrm{TWR}}\right) \mathbf{=} \mathbf{- 0 , 0 0 9}+\mathbf{0 , 7 5 2}$ $\mathbf{E}\left(\mathbf{R}_{\mathbf{M}}\right)$. Di mana: Alfa $=-0,009$; artinya apabila tingkat pengembalian pasar adalah 0 (ditunjukkan dengan IHSG), maka tingkat pengembalian saham $E\left(R_{P G A S}\right)$ sebesar 0,009 (negatif). Beta $=0,752$; artinya setiap ada kenaikan return pasar sebesar $1 \%$, maka return saham Telkom Indonesia (Persero) Tbk akan mengalami kenaikan sebesar 0,0752\%, dan sebaliknya.

Menghitung required return (tingkat pengembalian yang diharapkan oleh investor untuk sekuritas). Required return merupakan tingkat pengembalian minimum yang diperlukan untuk berinvestasi (Salim \& Abu, 2018). Sebelum mencari required return (RR) diperlukan data tentang aset bebas risiko (Rf), yang ditunjukkan dengan BI 7Days Repo Rate dan data IHSG. Tabel 3 di atas telah ditunjukkan BI 7Days Repo Rate dan IHSG. BI 7Days Repo Rate digunakan untuk menghitung risk free (Rf), sedangkan IHSG untuk menujukkan return pasar $E\left(R_{M}\right)$. Tabel 7 menunjukkan required return tiap saham.

Tabel 7. Required Return tiap Saham

\begin{tabular}{ccccc} 
& $\mathrm{Rf}$ & $\beta \mathrm{i}$ & $\mathrm{E}(\mathrm{Rm})$ & $\mathrm{RR}$ \\
\hline ANTM & 0,042 & 2,167 & $(0,005)$ & $-0,0602$ \\
PGAS & 0,042 & 2,297 & $(0,005)$ & $-0,0664$ \\
TOWR & 0,042 & 0,738 & $(0,005)$ & 0,0074 \\
BBRI & 0,042 & 1,257 & $(0,005)$ & $-0,0171$ \\
TLKM & 0,042 & 0,752 & $(0,005)$ & 0,0067 \\
\hline
\end{tabular}

Sumber: Hasil Pengolahan Data (2021)

Dari tabel 7, dapat diketahui bahwa tingkat pengembalian yang diminta oleh investor (required return) terbesar adalah PT Tower Bersama Infrastructure Tbk sebesar 0,74\%, sedangkan required return terkecil pada Perusahaan Gas Negara Tbk sebesar -6,64\%. Excess return adalah selisih antara $\mathrm{E}(\mathrm{Ri})$ dengan $\mathrm{RR}$, yang menunjukkan selisih tingkat pengembalian dari suatu saham dengan tingkat pengembalian yang diharapkan oleh investor (Setyawati, 2014). Besarnya excess return ditunjukkan oleh tabel 9.

Tabel 9. Excess Return

\begin{tabular}{ccccc} 
& $\mathrm{E}(\mathrm{Ri})$ & Required return & Excess Return & Tingkat Kelayakan \\
\hline ANTM & 0,0588 & $-0,0602$ & 0,1190 & Layak \\
PGAS & $-0,0118$ & $-0,0664$ & 0,0546 & Layak \\
TOWR & 0,0340 & 0,0074 & 0,0266 & Layak \\
BBRI & 0,0001 & $-0,0171$ & 0,0172 & Layak \\
TLKM & $-0,0130$ & 0,0067 & $-0,0197$ & Tidak layak \\
\hline
\end{tabular}

Sumber: Hasil Pengolahan Data (2021)

Berdasarkan tabel 9, excess return hampir semua saham perusahaan yang masuk dalam kategori LQ45 periode Agustus 2019 - Juli 2021 bernilai positif, artinya investor layak jika menginvestasikan dananya pada saham-saham tersebut. Investasi yang tidak layak ditanamkan terjadi pada perusahaan, Telkom Indonesia (Persero) Tbk. (TLKM). Sedangkan saham yang layak untuk dibeli oleh investor adalah saham perusahaan Aneka Tambang (Persero), Tbk, Perusahaan Gas Negara, Tbk, Tower Bersama Infrastructure Tbk. (TOWR) dan Bank Rakyat Indonesia (Persero), Tbk, karena memiliki excess return positif. Indeks LQ45 menunjukkan kinerja 45 perusahaan yang listing di Bursa Efek Indonesia yang dengan proses seleksi yang 
ketat memiliki likuiditas tinggi (LiQuid). Di samping itu perusahaan tersebut memiliki kriteria lainnya, seperti memiliki kapitalisasi pasar tertinggi yang ditunjukkan dengan volume perdagangan dalam 12 bulan terakhir (Setyawati, 2014). Saham dengan indeks LQ45 termasuk saham yang aktif dalam perdagangan yang ditunjukkan dengan perubahan harga yang terus menerus. Saham perusahaan yang masuk dalam indeks LQ45 termasuk dalam saham blue chip, karena perusahaannya diakui secara nasional, mature, dan sehat secara keuangan.

Penelitian tentang pembentukan portfolio optimal saham telah banyak dilakukan oleh beberapa peneliti dan penelitian mereka menunjukkan hasil yang berbeda-beda. . Penelitian Purba et al., (2014) menunjukkan bahwa saham Telkom Indonesia (Persero) Tbk. Layak untuk investasi. Penelitian Anish et al. (2019) menunjukkan bahwa saham Adaro Energy Tbk. dan Telkom Indonesia (Persero) Tbk. merupakan perusahaan yang sahamnya layak bagi investor. Penelitian Febrilian (2019) menunjukkan bahwa saham Adaro Energy Tbk. layak untuk dibeli oleh investor. Dari beberapa penelitian di atas yang dilakukan pada periode $2014-2019$, menunjukkan kalau Telkom Indonesia (Persero) Tbk. merupakan perusahaan yang diakui secara nasional, mature, dan sehat secara keuangan, sehingga layak untuk investor untuk menginvestasikan dananya ke perusahaan tersebut. Sedangkan dalam penelitian ini, Telkom Indonesia (Persero) Tbk merupakan saham yang tidak layak untuk diinvestasikan.

Pasar modal yang menganut sistem ekonomi liberal dan terbuka, di mana semua orang bebas untuk mendapatkan akses berbagai informasi yang akurat menyebabkan adanya keterkaitan antara satu bursa efek dan bursa efek lainnya di berbagai belahan dunia. Hasil penelitian dari Markwat et al., (2009) menunjukkan bahwa jatuhnya perdagangan di bursa efek global terjadi dengan perlahan-lahan, dimulai dari bursa efek lokal dari satu negara kemudian menyebar dengan cepat ke negara lainnya. Inilah yang dinamakan dengan efek domino, di mana jatuhnya perekonomian suatu negara akan berimbas pada kinerja perekonomian negara lain. Hal itu mengingat perdagangan internasioal maupun keuangan internasional merupakan mata rantai produksi barang, jasa dan modal melibatkan negara lain sebagai pemasok bahan baku, pasar produk barang dan jasa, serta sebagai penyedia likuiditas keuangan.

\section{Kesimpulan}

Setelah penulis melakukan serangkaian perhitungan, maka penulis mengambil kesimpulan bahwa PT. Aneka Tambang (Persero), Tbk mempunyai tingkat pengembalian saham paling tinggi sebesar 5,9\%, kemudian, Tower Bersama Infrastructure Tbk mempunyai tingkat pengembalian sebesar $3,4 \%$, dan Bank Rakyat Indonesia (Persero), Tbk mempunyai tingkat pengembalian sebesar $0,06 \%$. Sedangkan dua perusahaan lainnya mempunyai tingkat pengembalian yang negatif, yaitu Perusahaan Gas Negara, Tbk sebesar $-1,2 \%$ dan Telkom Indonesia (Persero) Tbk sebesar -0,13\%. Saham PT. Aneka Tambang (Persero), Tbk mempunyai tingkat risiko terbesar, yaitu 22,3\%; Perusahaan Gas Negara, Tbk mempunyai tingkat risiko sebesar 17,9\%, Tower Bersama Infrastructure Tbk mempunyai tingkat risiko 12,2\%, Bank Rakyat Indonesia (Persero), Tbk dengan tingkat risiko sebesar10,3\% dan 
perusahaan yang sahamnya mempunyai tingkat risiko terkecil adalah Telkom Indonesia (Persero) Tbk sebesar $8,2 \%$. Hal ini berarti tingkat pengembalian saham berbanding lurus dengan tingkat risiko. Semakin tinggi tingkat pengembalian saham maka semakin tinggi risikonya. Excess return hampir semua saham perusahaan yang masuk dalam kategori LQ45 periode Agustus 2019 - Juli 2021 bernilai positif, artinya investor layak jika menginvestasikan dananya pada saham-saham tersebut. Investasi yang tidak layak ditanamkan terjadi pada saham perusahaan Telkom Indonesia (Persero) Tbk. Saham yang layak untuk dibeli oleh investor adalah saham perusahaan PT. Aneka Tambang (Persero), Tbk, Perusahaan Gas Negara, Tbk, Tower Bersama Infrastructure Tbk. (TOWR) dan saham perusahaan Bank Rakyat Indonesia (Persero), Tbk, karena memiliki excess return positif. Penelitian ini hanya difokuskan untuk kelayakan investasi pada 5 (lima) saham perusahaan kapitalisasi terbesar di BEI. Penelitian berikutnya dapat dilakukan dengan menghitung kelayakan pada semua sahamsaham yang terindeks di LQ45 ataupun indeks sektoral lainnya di BEI. Penelitian berikutnya juga bisa menilai kelayakan investasi salam perusahaan di bursa efek luar negeri.

\section{Ucapan Terima Kasih}

Peneliti mengucapkan terimakasih kepada Rektor Universitas Nasional melalui SK Nomor 90 Tahun 2021 tentang penetapan Bantuan Stimulus Penelitian untuk Dosen Universitas Nasional Semester Genap Tahun Akademik 2020/2021, Tanggal 5 Mei 2021 dan Dekan Fakultas Ekonomi dan Bisnis yang telah memberi kesempatan bagi kami untuk melakukan penelitian ini.

\section{Daftar Pustaka}

Harshita, Singh, S., \& Yadav, S. S. (2015). Indian Stock Market and the Asset Pricing Models. Procedia Economics and Finance, 30(15), 294-304. https://doi.org/10.1016/s22125671(15)01297-6

Jayana, N. S., \& Gayatri, H. W. (2018). Selection of Leading Sectors Share Portfolio using Capital Asset Pricing Model ( Capm ) in Indonesia Stock Exchange ( IDX) Period February 2012-March. International Journal of Innovatif Science and Research Technology, 3(6).

Marling and, \& Emanuelsson. (2012). The Markowitz Portfolio Theory. Survey Online Http://Www. Math. Chalmers. Se, 1-6. http://www.math.chalmers.se/Stat/Grundutb/CTH/mve220/1213/gr1_HannesMarling_Sara Emanuelsson_MPT.pdf

Matsuk, Z., Shyiko, V., Danyliuk-Chernykh, I., \& Tryshak, L. (2019). Rating of Investments Funds Using the Capital Asset Pricing Model: Experience of Ukraine. 99(Mdsmes), 1-5.

Ogiugo, H. U., Adesuyi, I. O., \& Ogbeide, S. O. (2020). Empirical test of capital asset pricing model on securities return of listed firms in Nigeria. Insights into Regional Development, 2(4), 825-836. https://doi.org/10.9770/ird.2020.2.4(8) 
Oldfield, G. S., \& Santomero, A. M. (2014). The Place of Risk Management in Financial Institutions.

Salim, F., \& Abu, N. A. (2018). A novel S-curve on capital asset pricing model. Science International (Lahore), 30(3), 471-475. http://www.sciint.com/pdf/636668069837279208.pdf

Setyawati, I. (2014). Analisis Portfolio Optimal dari 10 Saham Unggulan di Bursa Efek Indonesia dengan Menggunakan Single Index Model. Mediastima, XX(1), 49-65.

Setyawati, I. (2018). Global financial crisis 2008 and its vulnerability in SAARC countries. Busness and Economic Horizons, 14(4), 766-776.

Širůček, M., \& Křen, L. (2015). Application of Markowitz portfolio theory by building optimal portfolio on the US stock market. Acta Universitatis Agriculturae et Silviculturae Mendelianae Brunensis, 63(4), 1375-1386. https://doi.org/10.11118/actaun201563041375

Wu, M., Imran, M., Feng, Y., Zhang, L., \& Abbas, M. (2017). Review and Validity of Capital Asset Pricing Model: Evidence from Pakistan Stock Exchange. International Research in Economics and Finance, 1(1), 21. https://doi.org/10.20849/iref.v1i1.267 